\title{
The Effect of $\mathrm{PGF}_{2 \alpha}, \mathrm{GnRH}, \mathrm{E}_{2}$ or Antibiotics on the Intrauterine Environment and Reproduction in Holstein Dairy Cows with Retained Placentas
}

\section{Kazuyuki Kaneko*}

Department of Veterinary Obstetrics and Gynecology, Azabu University, 1-17-71 Fuchinobe, Chuo-ku, Sagamihara, Kanagawa 229-8501, Japan

\begin{abstract}
$\mathrm{PGF}_{2 \mathrm{~g}}, \mathrm{GnRH}$, estradiol $\left(\mathrm{E}_{2}\right)$, or antibiotics were given to dairy cows with retained placenta after parturition to establish the most suitable treatment to prevent the development of endometritis. One hundred and seventy five parous Holstein cows with retained placenta were allocated to into six treatment groups, and groups were given PGF2a, GnRH, $E_{2}$, or antibiotics at 30 or 45 days after parturition. The intrauterine perfusion fluid was collected at 60 days after parturition, and a bacteriological and cytological examination was conducted. Reproductive performance was also investigated. The detection rate for Trueperella pyogenes in the intrauterine perfusion fluid in each group ranged from $0 \%$ to $16 \%$, and T. pyogenes was not isolated in cows that were given PGF2 $\alpha$ or $\mathrm{E}_{2}$. The percentage of neutrophils observed in the intrauterine perfusion fluid ranged from $37.8 \pm 5.3$ to $56.3 \pm 4.7$, and it was lowest in cows given PGF2 $\alpha$ and highest in cows given GnRH. The mean number of days from parturition to initial insemination, the mean number of days from parturition to conception and the mean number of artificial inseminations required for conception ranged from $85.9 \pm 5.5$ to $102.7 \pm 8.0,103.8 \pm 9.0$ to $162.3 \pm 18.6$ and $1.5 \pm 0.2$ to $2.6 \pm 0.3$, respectively. All three parameters were best in cows that were given a combination of PGF2 $\alpha$ and $E_{2}$. The results suggest that administration of PGF2 $\alpha$ or $E_{2}$, or ideally both, might be a suitable treatment for cows with retained placenta. However, treatment with $\mathrm{GnRH}$ might delay the cleansing of the uterus.
\end{abstract}

Keywords: Cattle; Endometritis; Reproductive performance; Retained placenta; Uterine perfusion

\section{Introduction}

Dystocia, retained placenta, injury of the birth canal and uterine prolapse in Holstein dairy cows are considered to be responsible for the delay in purification of the uterus following parturition. Of these factors, retained placenta is the most frequent and seriously affects subsequent fertility owing to the development of metritis [1-4]. Proper treatment for placental retention is, therefore, considered important in the management of reproduction. There are many reported treatment methods to prevent endometritis after retained placenta, and the application of PGF2 $\alpha, \mathrm{GnRH}$, estradiol $\left(\mathrm{E}_{2}\right)$, or antibiotics is preferentially used [1,5-7]. Kaneko et al. [8,9] reported that the uterus of cows with retained placenta was easily infected with Trueperella pyogenes (T. pyogenes), and that they tended to suffer from endometritis. Furthermore, the percentage of neutrophils in the cells observed in the intrauterine perfusion fluid was high in the uterus after the placenta was retained when compared to a uterus without retained placenta. The purpose of this study was to examine the effects of administration of PGF2a, GnRH, $E_{2}$, or antibiotics on the presence of T. pyogenes in the uterus, the percentage of neutrophils, and the subsequent reproductive performance in Holstein dairy cows with retained placenta.

\section{Materials and Methods}

\section{Animals}

Two hundreds parous Holstein cows $\geq 2$ years old ( $3.8 \pm 0.5$ : mean \pm SEM) were used. The cows were housed in barn stalls at 15 dairy farms, fed a total mixed ration and had free access to water. Their BCS was 2.5 to 4.0 , and their milk volume was 25 to $40 \mathrm{Kg}$ /day. Of the 200 cows, 175 did not expel the placenta within 24 hours of calving and were diagnosed with retained placenta. The remaining 25 cows expelled their placenta within 24 hours of calving and were assigned to the control group
(Group C). All cows diagnosed with retained placenta spontaneously expelled the placenta within 7-10 days of parturition without any medical intervention, and they were allocated into one of six treatment groups. All treatments were carried out with approval from the ethics committee of Azabu University.

\section{Treatment}

Cows with retained placenta were randomly assigned into one untreated group and the following six treatment groups each consisting of 25 cows. Group NT: no treatment was given. Group GnRH: cows were treated with an IM injection of $200 \mu \mathrm{g}$ of fertirelin acetate at 30 days' post parturition. Group ABP: cows were treated with an IU infusion of $500 \mathrm{mg}$ of ampicillin administered at 30 days' post parturition. Group E: cows were treated with an IM injection of $5 \mathrm{mg}$ of estradiol benzoate at 30 days' post parturition. Group FS: cows were treated with an SC injection of $1 \mathrm{mg}$ of fenprostalene at 30 days' post parturition. Group DP: cows were treated with an IM injection of $25 \mathrm{mg}$ of dinoprost at 45 days' post parturition. Group E+DP: cows were initially treated with 5 $\mathrm{mg}$ of estradiol benzoate administered by IM injection at 30 days' post parturition, followed by an IM injection of $25 \mathrm{mg}$ dinoprost at 45 days post parturition.

*Corresponding author: Kazuyuki K, Department of Veterinary Obstetrics and Gynecology, Azabu University, 1-17-71 Fuchinobe, Chuo-ku, Sagamihara, Kanagawa 229-8501, Japan, Tel: 0428502454; Fax: 042-850-2454; E-mail: kaneko@azabu-u.ac.jp

Received February 04, 2017; Accepted May 16, 2017; Published May 19, 2017

Citation: Kaneko K (2017) The Effect of PGF ${ }_{20}, \mathrm{GnRH}_{1} \mathrm{E}_{2}$ or Antibiotics on the Intrauterine Environment and Reproduction in Holstein Dairy Cows with Retained Placenta. J Vet Sci Technol 8: 444. doi: 10.4172/2157-7579.1000444

Copyright: @ 2017 Kaneko K. This is an open-access article distributed under the terms of the Creative Commons Attribution License, which permits unrestricted use, distribution, and reproduction in any medium, provided the original author and source are credited. 
Citation: Kaneko K (2017) The Effect of $\mathrm{PGF}_{2 \mathrm{a}}, \mathrm{GnRH}, \mathrm{E}_{2}$ or Antibiotics on the Intrauterine Environment and Reproduction in Holstein Dairy Cows with Retained Placenta. J Vet Sci Technol 8: 444. doi: 10.4172/2157-7579.1000444

\section{Collection of intrauterine perfusion fluid}

The intrauterine perfusion fluid was collected using the method of Kaneko et al. [8] at 60 days after parturition. A speculum was inserted into the vagina after cleansing of the vulva with a disinfectant, and the tip of a balloon catheter (Terumo Inc., Tokyo, Japan, Fr 22) was inserted into the cervix as deeply as possible without touching the vaginal wall. The vaginal speculum was then removed, the balloon catheter was advanced into the uterus using the reto-vaginal method, and the balloon was inflated. Sterile physiological saline $(100 \mathrm{~mL})$ was infused into the uterus through a balloon catheter and recovered by gently massaging the uterus.

\section{Bacteriological examination of intrauterine perfusion fluid}

The perfusion fluid $(10 \mathrm{~mL})$ was centrifuged at $1,000 \times \mathrm{g}$ for $10 \mathrm{~min}$ and after removing the supernatant, the sediment was resuspended in 1 $\mathrm{ml}$ of physiological saline. An aliquot of the resuspended sediment (100 $\mu \mathrm{L}$ ) was applied to soy agar with $5 \%$ sheep blood, and incubated at $37^{\circ} \mathrm{C}$ for 48 hours. Gram-negative, atypical, pine leaf-like rods, which showed a hemolytic reaction on sheep blood-containing agar medium and were catalase negative, were judged to be T. pyogenes. According to Kaneko et al. [8], a sample showing growth of one or more T. pyogenes colonies was defined as positive for T. pyogenes.

\section{Cytological examination of intrauterine perfusion fluid}

The perfusion fluid $(10 \mathrm{~mL})$ was centrifuged as described above and the sediment was smeared onto a glass slide, air dried, fixed for 3 mins with methyl alcohol and stained with Giemsa stain. Two hundred cells were counted at $\times 1,000$ for each specimen and classified into neutrophils, eosinophils, basophils, lymphocytes and macrophage-like cells. The percentage of neutrophils was calculated.

\section{Reproductive performance}

The number of days from parturition to initial insemination, the number of days until conception and the number of inseminations required to achieve conception in these cows were investigated.

\section{Statistical analysis}

The T. pyogenes detection rate was compared between groups using a chi-square test. The percentage of neutrophils and the reproductive performance were compared between groups using Student's t test.

\section{Results}

\section{The rate of detection of $T$. pyogenes}

The rate of T. pyogenes detection ranged from $0 \%$ (Group E, Group FS and Group E+DP) to $16 \%$ (Group NT). However, there was no significant difference between the groups (Table 1).

\section{The percentage of neutrophils in intrauterine perfusion fluid}

The mean percentage of neutrophils ranged from $37.8 \pm 5.3$ (Group C) to $56.3 \pm 4.7$ (Group GnRH). Group DP was found to have the lowest $(40.7 \pm 5.9)$ mean percentage of neutrophils of the treated groups. The mean percentage of neutrophils in Group $\mathrm{GnRH}$ was significantly higher than the means in Group C, Group E, Group FS, Group DP and Group E+DP $(\mathrm{P}<0.05)$ (Table 1).

\section{Reproductive performance}

The number of cows in each group that was used for reproduction after parturition was 19 in Group C, 20 in Group NT, 19 in Group
GnRH, 19 in Group ABP, 16 in Group E, 15 in Group FS, 19 in Group DP and 18 in Group E+DP. The mean number of days from parturition to initial insemination ranged from $85.9 \pm 5.5$ (Group E+DP) to $102.7 \pm$ 8.0 (Group E). The mean number of days from parturition to conception ranged from $103.8 \pm 9.0$ (Group E+DP) to $162.3 \pm 18.6$ (Group ABP). The mean number of artificial inseminations required for conception ranged from $1.5 \pm 0.2$ (Group E+DP) to $2.6 \pm 0.3$ (Group ABP). All three parameters were lowest in Group E+DP and there was a significant difference between Group E+DP and some of the other groups in the three parameters (Table 2).

\section{Discussion}

Each treatment method used in this study was based on the following facts. $E_{2}$ facilitates the evacuation of exudate in the uterus by causing contraction of the uterus and relaxation of the cervix [10]. Furthermore, $\mathrm{E}_{2}$ increases peripheral blood neutrophil counts $[11,12]$ and its function is enhanced under estrogen domination [13]. GnRH stimulates follicular growth after parturition and increases the blood estrogen level. For this reason, $\mathrm{GnRH}$ has been used to treat endometritis after retained placenta $[5,14]$. PGF2 $\alpha$ regresses the corpus luteum and induces estrous causing blood estrogen levels to increase. It was reported previously that PGF2 $\alpha$ is effective for treatment of endometritis [15-17]. In particular, fenprostalene was reported to exert a strong direct contractile action on the myometrium as well as causing a luteolytic effect. Furthermore, the effect of fenprostalene is long-lasting $[18,19]$. The beneficial effect of antibiotics as an intrauterine therapy has been reported for the treatment of retained placenta or endometritis in dairy cows $[18,20]$.

There was no significant difference between the groups in the detection rate of $T$. pyogenes. Kaneko et al. reported that $T$. pyogenes

\begin{tabular}{|c|c|c|}
\hline & $\begin{array}{c}\text { The number of cows having } \\
\text { T. pyogenes }\end{array}$ & $\begin{array}{c}\text { Percentage of neutrophilus } \\
\text { (mean } \pm \text { SEM) }\end{array}$ \\
\hline Group C & $1(4 \%)$ & $37.8 \pm 5.3^{\mathrm{a}}$ \\
\hline Group NT & $4(16 \%)$ & $53.8 \pm 5.9$ \\
\hline Group GnRH & $2(8 \%)$ & $56.3 \pm 4.7^{\mathrm{b}}$ \\
\hline Group ABP & $2(8 \%)$ & $49.1 \pm 4.3$ \\
\hline Group E & $0(0 \%)$ & $41.9 \pm 5.0^{\mathrm{c}}$ \\
\hline Group FS & $0(0 \%)$ & $41.4 \pm 4.7^{\mathrm{c}}$ \\
\hline Group DP & $2(8 \%)$ & $40.7 \pm 5.9^{c}$ \\
\hline Group E+DP & $0(0 \%)$ & $40.9 \pm 4.7^{\mathrm{c}}$ \\
\hline
\end{tabular}

Group C: no retained placenta, Group NT: no treatment, Group GnRH: fertirelin acetate given IM, Group ABP: ampicillin given IU, Group E: estradiol benzoate given IM, Group FS: fenprostalene given SC, Group DP: dinoprost given IM, Group E+DP estradiol benzoate and dinoprost given IM. a,b, $\mathrm{P}<0.01$, b,c, $\mathrm{P}<0.05$.

Table 1: The results of bacteriological and cytological examination of intrauterine perfusion fluid $(n=25)$.

\begin{tabular}{|l|c|c|c|}
\hline & $\begin{array}{c}\text { Days to first } \\
\text { insemination }\end{array}$ & $\begin{array}{c}\text { Days to } \\
\text { conception }\end{array}$ & $\begin{array}{c}\text { Number of Al to } \\
\text { conception }\end{array}$ \\
\hline Group C $(n=19)$ & $89.9 \pm 8.3$ & $126.5 \pm 12.6$ & $1.8 \pm 0.2$ \\
\hline Group NT $(n=20)$ & $88.0 \pm 5.5$ & $133.7 \pm 14.0$ & $2.0 \pm 0.2$ \\
\hline Group GnRH $(n=19)$ & $91.5 \pm 6.2$ & $143.4 \pm 13.7^{c}$ & $2.1 \pm 0.3$ \\
\hline Group ABP $(n=19)$ & $91.1 \pm 6.4$ & $162.3 \pm 18.6^{d}$ & $2.6 \pm 0.3^{\mathrm{h}}$ \\
\hline Group E $(n=16)$ & $102.7 \pm 8.0^{\mathrm{a}}$ & $150.8 \pm 17.3^{\mathrm{e}}$ & $2.1 \pm 0.3$ \\
\hline Group FS $(n=15)$ & $92.3 \pm 3.5$ & $124.9 \pm 16.1$ & $2.0 \pm 0.5$ \\
\hline Group DP $(n=19)$ & $97.0 \pm 8.4$ & $155.4 \pm 13.4^{\mathrm{f}}$ & $2.1 \pm 0.3$ \\
\hline Group E+DP $(n=18)$ & $85.9 \pm 5.5^{\mathrm{b}}$ & $103.8 \pm 9.0^{\mathrm{g}}$ & $1.5 \pm 0.2^{\mathrm{i}}$ \\
\hline
\end{tabular}

CF: dg,fg,hi; $P<0.01$, ab,cg,eg; $P<0.05$.

Table 2: Reproductive performance in each group (Mean \pm SEM). 
Citation: Kaneko K (2017) The Effect of $\mathrm{PGF}_{2 a}, \mathrm{GnRH}, \mathrm{E}_{2}$ or Antibiotics on the Intrauterine Environment and Reproduction in Holstein Dairy Cows with Retained Placenta. J Vet Sci Technol 8: 444. doi: 10.4172/2157-7579.1000444

was isolated from $56 \%$ of cows with retained placenta at 30 days after parturition, but this decreased to $12 \%$ at 60 days after parturition in cows that spontaneously expelled their placenta without any treatment [9]. In this study, the rate of T. pyogenes detection in Group NT was $16 \%$ which was similar to Kaneko's findings. However, T. pyogenes was not isolated in Group E, Group FS and Group E+DP. This is an important result because T. pyogenes induces metritis by synergism with gramnegative bacilli such as Fusobacterium necrophorum or Dichelobacter melaninogenicus which have been shown to reduce fertility $[2,6,21,22]$. T. pyogenes was isolated from two cows in Group ABP. It was reported that intrauterine infusion of antibiotics was ineffective in preventing intrauterine infection in a postpartum dairy cow with retained placenta $[23,24]$.

Kaneko et al. performed a cytological examination of intrauterine perfusions and reported that the percentage of neutrophils was higher in the uterus of cows with retained placenta at 30 or 60 days after parturition [9]. In this study, the percentage of neutrophils was lowest in Group C indicating that the retained placenta has a negative effect on clearance of the intrauterine environment. The percentage of neutrophils was highest in Group GnRH. GnRH induces ovulation and development of the corpus luteum causing the progesterone level in the blood to increase. Progesterone causes closure of the cervix, reduction of uterine contractions and increases the susceptibility of the uterus to infection [25]. Therefore, GnRH administration at around this time, when bacterial infection, especially $T$. pyogenes, is dominant [9], might be disadvantageous to the cleansing of the uterus following retained placenta $[25,26]$. On the other hand, it was relatively low in the groups to which PGF2 $\alpha$ or $\mathrm{E}_{2}$ were given [Group E, Group FS, Group DP and Group E+DP]. This might suggest that $\mathrm{PGF} 2 \alpha$ or $\mathrm{E}_{2}$ have a positive effect on clearance of the intrauterine environment. PGF2 $\alpha$ administration has been shown to induce estrus and positively influence uterine involution in cows with luteal tissue [27].

The reproductive performance in Group E+DP was the best in terms of the number of days from parturition to initial insemination, the number of days until conception and the number of inseminations required to achieve conception. This was even better than in cows that did not have retained placenta (Group C). The absence of any improvement in reproductive performance in Group E and Group DP indicates that there might have been a synergism between estradiol benzoate and dinoprost. Estradiol, in combination with dinoprost, has been shown to reduce intrauterine bacterial contamination [28]. In addition, only Group E+DP received two treatments, and repeated exposure of the uterus to estrogen might have facilitated the clearance of the intrauterine environment.

Based on the detection rate of T. pyogenes, the cytology results, and the reproductive performance, we propose that administration of PGF2 $\alpha$ or $E_{2}$, especially in combination, might be a suitable treatment for cows with retained placenta. We also provide evidence that the use of GnRH might cause a delay in the cleansing of the uterus.

\section{Conflicts of Interest}

Authors have none to declare.

\section{References}

1. Bartolome JA, Khalloub P, Luzbel de la Sota R, Drillich M, Melendez PG (2014) Strategies for the treatment of dairy cows at high risk for postpartum metritis and for the treatment of clinical endometritis in Argentina. Trop Anim Health Prod 46: 79-85.
2. Kaneene JB, Miller R (1994) Epidemiological study of metritis in michgan dairy cattle. Vet Rec 25: 253-257.

3. Machado VS, Bicalho ML, Pereira RV, Caixeta LS, Bittar JH, et al. (2012) The effect of intrauterine administration of mannose or bacteriophage on uterine health and fertility of dairy cows with special focus on Escherichia coli and Arcanobacterium pyogenes. J Dairy Sci 95: 3100-3109.

4. Machado VS, Oikonomou G, Ganda EK, Stephens L, Milhomem M, et al. (2015) The effect of intrauterine infusion of dextrose on clinical endometritis cure rate and reproductive performance of dairy cows. J Dairy Sci 98: 3849-3858.

5. Bosu WTK, Peter AT, DeDecker RJ (1998) Short-term changes in serum luteinizing hormone, ovarian response and reproductive performance following gonadotrophin releasing hormone treatment in postpartum dairy cows with retained placenta. Can J Vet Res 52: 165-171.

6. Sheldon IM, Dobson H (2004) Postpartum uterine health in cattle. Anim Reprod Sci 82: 295-306.

7. Sheldon IM, Noakes DE (1998) Comparison of three treatments for bovine endometritis. Vet Rec 142: 575-579.

8. Kaneko K, Kawakami S, Miyoshi M, Abukawa T, Yamanaka S, et al. (1996) Bacteriological and cytological examination of the uterine perfusate in cows. $J$ Jap Vet Med Assoc 49: 435-438.

9. Kaneko K, Kawakami S, Miyoshi M, Abukawa T, Yamanaka S, et al. (1997) Effect of retained placenta on subsequent bacteriological and cytrogical intrauterine environment and reproduction in Holstein dairy cows. Theriogenology 48: 617-624.

10. Gustafson BK (1984) Therapeutic strategies involving antimicrobial treatment of the uterus in large animals. J Am Vet Med Asso 185: 1194-1198.

11. Lamote I, Meyer E, De Ketelaere A, Duchateau L, Burvenich C (2006) Expression of the estrogen receptor in blood neutrophils of dairy cows during the periparturient period. Theriogenology 65: 1082-1098.

12. Martinez PE, Lopes MTP, Martins MS, Marques Jr AP, Salas CE (1998) Changes in glucocorticoid receptor levels of lymphocyte and neutrophil during estrous cycle. Reprod Dom Anim 33: 61-66.

13. Roth JA, Kaeberle ML, Appell LH, Nachreiner RF (1983) Association of increased estradiol and progesterone blood values with altered bovine polymorphonuclear leukocyte function. Am J Vet Res 44: 247-253.

14. Mori J, Ouchi K, Kawate N, Inaba T (1988) GnRH-analogue leads to improved breeding efficiency in cows with retained fetal membranes. Vet Rec 123: 352.

15. Etherington WG, Kelton D, Adams J (1994) Reproductive performance of dairy cows following treatment with fenprostalene, dinoprost or cloprostenol between 24 and 31 days postpartum: a field trial. Therigenology 42: 739-752.

16. Etherington WG, Martin SW, Bonnett B, Johnson WH, Miller RB, et al. (1998) Reproductive performance of dairy cows following treatment with cloprostenol 26 and/or 40 days postpartum: a field trial. Theriogenology 29: 565-75.

17. Kasimanickam R, Duffield TF, Foster RA, Gartley CJ, Leslie KE, et al. (2005) The effect of a single administration of cephapirin or cloprostenol on the reproductive performance of dairy cows with subclinical endometritis. Theriogenology 63: 818-830.

18. Garcia-Villar R, Marnet PG, Laurentie MP, Toutain PL (1985) Relative oxytocic properties of fenprostalene compared with cloprostenol, prostaglandin F2 $\alpha$ and oxytocin in the ovariectomized ewe. Am J Vet Res 46: 814-844.

19. Herschler RC, Lawrence JR (1984) A prostaglandin analogue for therapy of retained placentae. Vet Med 79: 822-826.

20. LeBlanc SJ, Duffield TF, Leslie KE, Bateman KG, Keefe GP, et al. (2002) The effect of treatment of clinical endometritis on reproductive performance in dairy cows. J Dairy Sci 85: 2237-2249.

21. Bonnett BN, Martin SW, Gannon VP, Miller RB, Etherington WG (1991) Endometrial biopsy in Holstein-Friesian dairy cows. III. Bacteriological analysis and correlations with histological findings. Can J Vet Res 55: 168-173.

22. Sheldon IM, Cronin J, Goetze L, Donofrio G, Schuberth HJ (2009) Defining postpartum uterine disease and the mechanisms of infection and immunity in the female reproductive tract in cattle. Biol Reprod 81: 1025-1032.

23. Stevens RD, Dinsmore RP, Cattell MB (1995) Evaluation of the use of intrauterine infusion of oxytetracycline, subcutaneous injection of fenprostalene, or a combination of both, for the treatment of retained fetal membranes in dairy cows. J Am Vet Med Asso 207: 1612-1615. 
Citation: Kaneko K (2017) The Effect of PGF ${ }_{2 a}, \mathrm{GnRH}_{1} \mathrm{E}_{2}$ or Antibiotics on the Intrauterine Environment and Reproduction in Holstein Dairy Cows with Retained Placenta. J Vet Sci Technol 8: 444. doi: 10.4172/2157-7579.1000444

Page 4 of 4

24. Whitacre MD (1992) Intrauterine infusion in the postpartum dairy cow. Vet Med 87: $376-381$

25. Etherington WG, Bosu WTK, Martin SW, Cote JF, Doig PA, et al. (1984) Reproductive performance in dairy cows following postpartum treatment with gonadotrophin releasing hormone and/or prostaglandin: A field trial. Can J Comp Ed 48: 245-250.
26. Lewis GS (2004) Steroidal regulation of uterine immune defenses. Anim Reprod Sci 82: 281-294.

27. Janowski T, Zduńczyk S, Mwaanga ES (2001) Combined GnRH and PGF2a application in cows with endometritis puerperalis treated with antibiotics. Reprod Dom Anim 36: 244-246.

28. Peters R, Laven RA (1996) Treatment of bovine retained placenta and its effects. Vet Rec 139: 535-539. 